\title{
Nomenclature of the ductus arteriosus
}

Sir,

It is over 30 years since the late Lord Brock affirmed that a ductus was, by definition, patent. He argued that the congenital lesion was the result of persistence and that the adjective patent was neither necessary nor contributory.

Now that echocardiographic studies ${ }^{1}$ have lent some support in clinical practice to histological distinctions $^{2}$ between delayed closure and congenital persistence, ${ }^{3}$ would it not be appropriate for the British Heart fournal to establish uniformity in nomenclature of the ductus?

Smallhorn and his colleagues ${ }^{1}$ have clarified their text by such expressions as "ductal patency" and "assessment of patency". Surely their message would also have been simplified and shortened by the omission of "patent" on each of the 25 occasions it preceded "ductus"? The plural form "ductuses" must be questioned as well. "Ductus" is not listed in standard dictionaries of English words; as a Latin word of the fourth declension its plural form is "ductus", which is more specific than the English translation "ducts".

\section{R M Marquis,}

M J Godman,

Department of Paediatric Cardiology,

Royal Hospital for Sick Children,

Edinburgh

\section{Editorial Note}

We entirely agree with the comments by Marquis and Godman and will be fortified in future in not acceding, as we had done, to the specific requests by the authors of the paper which has caused linguistic dis- $-\frac{6}{\omega}$ tress.

\section{References}

1 Smallhorn JF, Huhta JC, Anderson RH, Macartney FJ Suprasternal cross-sectional echocardiography in assess ment of patent ductus arteriosus. Br Heart $\mathcal{F} 1982 ; 48$ : $321-30$.

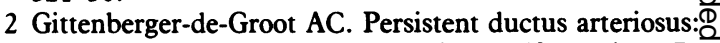
most probably a primary congenital malformation. $\mathrm{Br} \Rightarrow$ Heart F 1977; 39: 610-8.

3 Godman MJ, Marquis RM. Paediatric cardiology. Vol. II Heart disease in the newborm. Edinburgh and London: Churchill Livingston, 1979: 3. 